\title{
KARAKTERISASI WARNA BULU DAN UKURAN TUBUH SAPI BALI JANTAN PADA PETERNAKAN RAKYAT
}

\section{COAT COLOR AND BODY MEASUREMENTS CHARACTERIZATION OF BALI CATTLE MALE IN TRADITIONAL FARMING SYSTEM}

\author{
Oleh \\ Rajab
}

Jurusan Peternakan Fakultas Pertanian, Universitas Pattimura

Jln. Ir. M. Putuhena, Kampus Poka - Ambon, Kode Pos. 97233

E-mail : rajab.amir@gmail.com

\begin{tabular}{|l|l|}
\hline Diterima: 5 Maret 2021 & Disetujui 20 April 2021 \\
\hline
\end{tabular}

\begin{abstract}
Abstrak
Selain berdasarkan sifat genetik, bentuk luar pada ternak sapi juga menjadi kriteria dalam pemilihan bibit seperti calon pejantan. Penelitian ini bertujuan untuk mengidentifikasi pola warna bulu dan melakukan karakterisasi ukuran-ukuran tubuh seperti lingkar dada, tinggi pundak dan panjang badan sapi Bali jantan dengan kategori umur berbeda yang dipelihara secara tradisional pada peternakan rakyat. Penelitian ini menggunakan metode survey observatif. Total sebanyak 154 ekor sapi Bali diamati pola warna bulunya, dan sebanyak 29 ekor sapi Bali jantan dengan kategori umur berbeda diukur karakteristik ukuran tubuh meliputi lingkar dada, tinggi pundak dan panjang badannya. Data hasil penelitian ditabulasi dan dianalisis secara deskriptif. Berdasarkan hasil penelitian dapat disimpulkan pola warna bulu sapi Bali semuanya normal dengan proporsi merah bata mengkilap dan pudar masing-masing sebesar $64 \%$ dan $36 \%$. Lingkar dada, tinggi pundak dan panjang badan untuk umur $<1$ tahun $\left(\mathrm{I}_{0}\right)$ adalah sebesar 108,47, 86,92, dan 84,07 cm ; untuk umur 1-2 tahun $\left(\mathrm{I}_{1}\right)$ sebesar 120,62, 96,98, dan 96,61 cm; sedangkan untuk umur $>2$ tahun $\left(\mathrm{I}_{2}\right)$ masing-masing sebesar 144,75, 116,93, dan 112,22 cm. Ukuran tubuh sapi Bali jantan masih tergolong rendah dan belum memenuhi standar kualitas bibit sapi potong yang baik.
\end{abstract}

Kata kunci: Warna bulu, ukuran tubuh, sapi Bali, peternakan rakyat.

\section{Abstract}

The aims of this reseach were both to identification of coat color and to characterization several body measurements of Bali cattle male categorized in three types of age which reared in traditional farming system. The study conducted by using survey observatory method with total of 154 tails of beef cattle using for coat color identification and 29 tails of male Bali cattle were measured. Observed variables were coat color, chest circumference, shoulder height and body lenght. The data obtained were analyzed descriptively. The results showed that the distribution of Bali cattle with normal coat color was $100 \%$, but if diveded into native and unnative color then the frequencies were $64 \%$ and $36 \%$ respectively. The average rate of chest circumference, shoulder height and body lenght of male Bali cattle respectively were follows $108.47,86.92$, and $84.07 \mathrm{~cm}$ for $\mathrm{I}_{\mathrm{o}} ; 120.62,96.98$, dan $96.61 \mathrm{~cm}$ for $\mathrm{I}_{1}$; and $144.75,116.93$, and 112.22 for $\mathrm{I}_{2} \mathrm{~cm}$. The body size of male Bali cattle is still relatively low and does not meet the quality standards of good beef cattle.

Keywords: Coat color, body measurements, Bali cattle, traditional farming system. 


\section{PENDAHULUAN}

Sapi Bali merupakan plasma nutfah asli Indonesia sebagai aset sumberdaya genetik nasional dan juga masuk dalam aset dunia sebagi salah satu bangsa sapi yang ada di dunia yang tercatat berdasarkan catatan FAO yang perlu dipertahankan keberadaan dan kelestariannya (Hikmawaty et al., 2014).

Perbaikan mutu genetik ternak sifatsifat ekonomis seperti pertumbuhan dan produksi perlu dilakukan dalam upaya mendukung ketersediaan produksi daging sapi guna dalam menunjang program swasembada daging nasional. Sifat ekonomis ini umumnya dipengaruhi oleh faktor genetik dan lingkungan seperti tataksana pemeliharaan, ketersediaan pakan, dan faktor lainnya yang kompleks (Pundir et al., 2007). Sapi Bali umumnya dipelihara oleh peternak rakyat dengan sistem pemeliharaan masih bersifat tradisional dengan salah satunya kendala yaitu

Warna bulu merupakan sifat kualitatif pada sapi potong telah digunakan dalam identifikasi dan klasifikasi galur sapi tertentu dalam populasi ternak, selain itu juga sebagai marker atau penciri yang dapat memudahkan mengontrol kondisi ternak (Dauda et al., 2018). Menurunnya tingkat kualitas genetik ternak sapi salah satunya ditandai dengan adanya penyimpangan fisiologis ternak seperti adanya warna bulu yang menyimpang dari

Disamping berdasarkan sifat genetik (bangsa), bentuk luar juga menjadi kriteria dalam pemilihan bibit (pejantan). Bentuk atau ciri luar sapi mempunyai korelasi positif
Sapi Bali mempunyai keunggulan spesifik sumberdaya genetik ternak asli dengan ciri khas tertentu dan mempunyai kemampuan untuk berkembang dengan baik pada berbagai lingkungan tropik yang ada di Indonesia. Sapi bali juga memiliki performa produksi yang cukup bervariasi dan kemampuan reproduksi yang tetap tinggi (Syaiful et al., 2020).

terjadinya penurunan kualitas bibit (Handiwirawan dan Subandriyo, 2004). Peningkatan kualitas bibit sapi potong dapat dilakukan melalui seleksi terhadap bibit sapi potong yang baik, namun hal ini perlu didukung dengan penggunaan informasi yang tepat dan sederhana menyangkut karakteristik fenotip seperti warna bulu dan ukuran-ukuran tubuh dalam penentuan kriteria seleksi di lapangan (Gunawan dan Putera, 2016).

warna bulu aslinya (Soekardono et al., 2009). Pada umumnya, sapi Bali berwarna merah bata, sehingga apabila ada warna yang berbeda dari warna pada umumnya, maka terjadi penyimpangan. Dengan adanya klasifikasi sapi berdasarkan warna diharapkan dapat membantu untuk lebih cepat dalam mengidentifikasi jenis sapi yang dimiliki dalam satu peternakan (Cholissodin et al., 2015).

terhadap faktor genetik seperti laju pertumbuhan dan kualitas daging (Baharun et al., 2017). Seleksi sederhana berdasarkan linier ukuran tubuh masih relevan untuk diaplikasikan dalam upaya pemilihan bibit 
pada sapi potong yang akan dikembangkan lebih lanjut (Gunawan dan Putera, 2016). Selain itu linier ukuran tubuh mempunyai nilai heritabilitas sedang sampai tinggi dan memiliki korelasi yang tinggi dengan sifat pertumbuhan (Afolayan et al., 2002). Salah satu cara untuk mengukur pertumbuhan sapi potong dengan Dalam upaya mempertahankan eksistensi bangsa sapi potong lokal sebagai plasma nutfah indigenous, maka perlu dilakukan kegiatan penjaringan sapi-sapi lokal potensial yang ada di peternakan rakyat sebagai sumber bibit guna mendapatkan bibit yang berkualitas, dan secara sederhana melalui uji performan berdasarkan sifat kuantitatif dan kualitatif meliputi pengukuran, penimbangan

\section{METODE PENELITIAN}

Penelitian ini dilaksanakan selama tiga (3) bulan mengambil lokasi pada usaha peternakan sapi Bali rakyat yang umumnya secara tradisional ekstensif di kampung Kalobo, distrik Salawati Utara, Kabupaten Raja Ampat. Pertimbangan pemilihan lokasi ini karena (1) merupakan sentra pengembangan sapi potong, (2) pemeliharan sapi Bali masih

Penelitian ini menggunakan metode survey observatif. Sampel penelitian yang digunakan dalam penelitian didata berdasarkan semua sapi yang dapat dikumpulkan dan didentifikasi. Total sebanyak 154 ekor sapi Bali diamati pola warna bulunya, dan total sebanyak 29 ekor sapi Bali jantan dengan kategori umur berbeda diukur karakteristik ukuran tubuhnya. Jumlah sampel sapi Bali jantan yang diukur lebih sedikit karena (1) memperoleh nilai bobot badan sapi adalah menggunakan ukuran tubuh. Ukuran tubuh yang dapat digunakan untuk mengestimasi bobot badan diantaranya adalah tinggi pundak, panjang badan, dan lingkar dada (Ikhsanuddin et al., 2018).

dan penilaian (Hartati et al., 2009). Penelitian ini bertujuan untuk mengidentifikasi pola warna bulu dan melakukan karakterisasi ukuran-ukuran tubuh seperti lingkar dada, tinggi pundak dan panjang badan sapi Bali jantan dengan kategori umur berbeda yang dipelihara secara tradisional pada peternakan rakyat.

bersifat tradisional dimana sapi dilepas pada padang pengembalaan, (2) populasi sapi Bali merupakan yang terbanyak di wilayah tersebut, dan (3) dalam kampung ini dibangun UPTD Pembibitan dan Pengembangan Sapi Potong dimana peternak rakyat merupakan mitra dari UPTD dalam program inti plasma pengembangan sapi potong di wilayah tersebut.

umumnya peternak telah menjualnya akibat kondisi keuangan yang mendesak atau guna menambah pendapatn keluarga, dan (2) banyak sapi Bali jantan yang dilepas di hutan jauh dari lokasi pemukiman sehingga menjadi liar dan sulit untuk ditangkap dan diukur. Peralatan yang digunakan dalam penelitian ini yaitu kamera untuk dokumentasi, pita ukur, tongkat ukur dan alat tulis menulis. 
Peubah yang diamati dalam penelitian ini meliputi warna bulu dan ukuran-ukuran tubuh (meliputi lingkar dada, tinggi pundak, dan panjang badan). Terdapat banyak ukuran tubuh yang dapat digunakan sebagai penciri seekor ternak, namun hanya tiga kategori ukuran tubuh yang digunakan sebagai peubah penelitian ini karena umumnya lingkar dada, tinggi badan

Pengambilan data sebagai berikut (1) pola warna bulu diperoleh lewat pengamatan langsung di lapangan dan dibagi dalam kategori (normal dan menyimpang) dan (merah bata mengkilap dan pudar) ; (2) lingkar dada diukur pada bidang yang terbentuk mulai dari pundak sampai dasar dada di belakang siku dan tulang belikat menggunakan pita ukur dalam satuan

Data hasil penelitian ditabulasi dan dianalisis secara deskriptif. Data pola warna bulu dianalisis dengan menghitung frekuensi atau persentasenya, sedang data lingkar dada, tinggi pundak dan panjang badan dianalisis

\section{HASIL DAN PEMBAHASAN}

\section{Warna Bulu}

Warna bulu pada sapi merupakan sifat kualitatif yang umumnya hanya dikontrol oleh satu atau dua pasang gen, tidak sama sekali atau sangat sedikit dipengaruhi oleh faktor

Sapi Bali berdasarkan standarisasi mutu bibit mempunyai ciri khas pada pola warna tubuh bulunya, dan akan berubah sesuai usia terutama pada sapi jantan, sehingga termasuk hewan dimoprhism-sex. Umumnya warna merah bata ditemukan baik pada sapi jantan maupun betina, namun warna bulu pada jantan biasanya berubah dari merah bata menjadi (tinggi pundak atau tinggi gumba), panjang badan, yang dipakai sebagai ukuran statistik vital dalam pemilihan bibit sapi potong berdasarkan Peraturan Menteri Pertanian Nomor 54/Permentan/OT.140/10/2006 tentang Pedoman Pembibitan Sapi Potong yang Baik (Good Breeding Practice).

cm; (3) tinggi pundak diukur dari titik tertinggi pundak tegak lurus sampai tanah dengan menggunakan tongkat ukur dalam satuan $\mathrm{cm}$; dan (4) panjang badan diukur dari penonjolan bahu (tubersitas humeri) sampai penonjolan tulang duduk (tuber ischii) dengan menggunakan tongkat ukur dalam satuan $\mathrm{cm}$.

dengan menghitung rata-rata dan simpangan bakunya menurut Kaps dan Lamberson (2004). Analisis data dengan bantuan perangkat lunak Microsoft Office Excel 2010.

lingkungan (Kirkpatrick, 2015), mudah diamati sehingga mudah dimonitor sepanjang waktu, serta sering digunakan sebagai marker atau penciri untuk identifikasi dan klasifikasi galur atau rumpun tertentu dalam populasi ternak (Dauda et al., 2018 ; Kosgey et al., 2006). cokelat tua atau hitam setelah Sapi itu mencapai dewasa kelamin sejak umur 1,5 tahun dan menjadi hitam mulus pada umur 3 tahun. Warna hitam dapat berubah kembali menjadi merah bata apabila dikebiri, yang disebabkan pengaruh hormon testosterone. Warna putih ditemukan pada bagian belakang paha, pinggir bibir atas, dan pada kaki mulai 
dari tarsus dan carpus sampai batas pinggir atas kuku, bulu pada bagian dalam telinga. Bulu pada ujung ekor dan garis belut pada punggung

Karakteristik warna bulu sapi Bali pada peternakan rakyat di lokasi penelitian dapat dilihat pada Tabel 1. Hasil penelitian menunjukkan tidak terdapat pola warna bulu yang menyimpang dari pola warna bulu menurut standar bibit sapi Bali atau sebanyak $100 \%$ pola warna bulu sapi Bali yang diamati normal. Berdasarkan hasil pengamatan tidak terdapat penyimpangan warna bulu sapi Bali murni karena tidak terjadi perkawinan dengan bangsa sapi lain. Soekardono et al., (2009), pada sapi Bali rakyat terkadang ditemukan terdapat beberapa kelainan pola warna bulu berwarna hitam (Sampurna, 2011 ; Alamsyah, 2015).

sebagai indikasi telah adanya degradasi genetik pada sapi Bali. Di antaranya adalah sapi injim (warna tubuh sampai bulu telinga bagian dalam berwarna hitam sejak kecil, dan pada sapi jantan walaupun dikebiri tidak terjadi perubahan warna) dan sapi mores (adanya warna hitam atau merah pada bagian bawah yang mestinya berwarna putih). Kadangkadang bulu putih terdapat di antara bulu yang cokelat (merupakan bintik-bintik putih) yang merupakan kekecualian atau penyimpangan ditemukan sekitar kurang dari $1 \%$.

Tabel 1. Pola warna bulu sapi Bali pada peternakan rakyat.

\begin{tabular}{lc}
\hline Peubah & Jumlah \\
\hline Jumlah sampel (ekor) & 154 \\
Pola Warna & \\
$\quad$ Normal (\%) & 100 \\
$\quad$ Menyimpang (\%) & 0 \\
Kondisi Warna Bulu & \\
$\quad$ Mengkilap (\%) & 64 \\
$\quad$ Pudar (\%) & 36 \\
\hline
\end{tabular}

Bulu Sapi Bali dapat dikatakan bagus (halus) pendek-pendek dan mengkilap. Karena pola warna bulu dalam penelitian ini semuanya normal, maka pengamatan lanjutan dilakukan untuk mengidentifikasi pola warna bulu dengan kategori mengkilap atau memudar. Warna merah bata menunjukkan masih cukup murninya bibit sapi Bali yang diternakkan. Tabel 1 menunjukkan bahwa sapi Bali yang memiliki warna bulu merah bata mengkilap sebesar $64 \%$, sedangkan merah bata pudar sebanyak $36 \%$. Warna merah bata mengkilap kemungkinan karena rendahnya penerapan tatalaksana pemeliharaan ternak seperti ternak jarang dimandikan atau dibersihkan sehingga warna bulu kelihatan pucat, atau akibat ternak terserang penyakit cacingan (Gwaza et al., 2018). Meski demikian terdapat dugaan bahwa variasi warna bulu ini berkaitan dengan penurunan mutu genetik sapi Bali yang signifikan akibat proses silang dalam. 


\section{Ukuran Tubuh Sapi Bali Jantan}

Kemampuan produksi seekor ternak salah satunya dikaitkan dengan kecepatan pertumbuhannya (Chamdi, 2005). Karena berkorelasi positif maka kecepatan pertumbuhan dapat diketahui berdasarkan pertumbuhan dimensi ukuran tubuh. Sejalan

Berdasarkan ketentuan pemerintah umumnya lingkar dada, tinggi badan (tinggi pundak atau tinggi gumba), panjang badan, dan bobot badan dipakai sebagai ukuran statistik vital yang dijadikan sebagai kriteria pemilihan bibit sapi potong di Indonesia. Dengan dengan pertambahan umur ternak maka dimensi ukuran tubuh semakin meningkat. Pertumbuhan anak sapi pada masa prasapih umumnya dipengaruhi oleh kemampuan pedet menyusui pada induknya (Hikmawaty et al., 2018 ; Kusuma et al., 2018 ; Lukuyu et al. 2016).

demikian data ukuran tubuh sapi Bali jantan dengan kategori umur berbeda yang dikarakterisasi pada penelitian ini terdiri dari lingkar dada, tinggi pundak, dan panjang badan, seperti dapat dilihat pada Tabel 2 .

Tabel 2. Rataan \pm simpangan baku ukuran tubuh sapi Bali Jantan pada peternakan rakyat dengan kategori umur berbeda.

\begin{tabular}{lccc}
\hline \multirow{2}{*}{\multicolumn{1}{c}{ Peubah }} & \multicolumn{3}{c}{ Kategori Umur } \\
\cline { 2 - 4 } & $<1$ tahun $(\mathrm{Io})$ & $1-2$ tahun $\left(\mathrm{I}_{1}\right)$ & $>2$ tahun $\left(\mathrm{I}_{2}\right)$ \\
\hline Jumlah Sampel (ekor) & 6 & 13 & 10 \\
Lingkar Dada (cm) & $108,47 \pm 14,18$ & $120,62 \pm 10,56$ & $144,75 \pm 13,91$ \\
Tinggi Pundak $(\mathrm{cm})$ & $86,92 \pm 8,62$ & $96,98 \pm 4,61$ & $116,93 \pm 20,05$ \\
Panjang Badan $(\mathrm{cm})$ & $84,07 \pm 6,18$ & $96,61 \pm 6,56$ & $112,22 \pm 9,77$ \\
\hline
\end{tabular}

Lingkar dada dapat digunakan sebagai indikator kapasitas tubuh sapi, sebab semakin besar lingkar dada organ-organ yang terdapat di dalam rongga dada juga semakin besar seperti paru-paru dan jantung (Afolayan et al., 2002). Hasil penelitian menunjukkan sapi Bali jantan pada peternakan rakyat yang dipelihara secara tradisonal mempunyai rataan lingkar dada sebesar 108,47 cm, 120,62 cm, dan 144,7 $\mathrm{cm}$ masing-masing untuk kategori umur I0, I1, dan I2. Hasil penelitian ini masih jauh di bawah standar ukuran vital bibit sapi Bali dimana calon pejantan setidaknya memiliki lingkar dada sebesar $172 \mathrm{~cm}$ pada kategori umur 1,5 sampai 2 tahun (Zurahmah dan The,
2011). Dengan demikian sapi Bali jantan pada peternakan rakyat yang ada pada lokasi penelitian masih berada pada kategori rendah karena untuk sapi Bali jantan yang berumur lebih dari dua tahun saja lingkar dadanya hanya sebesar 144,7 cm. Pada kondisi pengaruh faktor galur, dan jenis kelamin yang relatif sama atau seragam, maka penyebab perbedaan ukuran lingkar dada diantaranya disebabkan oleh pengaruh genetik (Cam et al., 2010), umur (Lukuyu et al., 2016), sistem pemeliharaan dimana berkaitan dengan pakan yang diberikan kepada ternak sapi dan suhu serta iklim lingkungan di sekitar habitat sapi (Nsoso et al., 2003). 
Pertumbuhan tinggi pundak atau punuk pedet sapi bail jantan dan betina pada umur 0 6 bulan mengalami pertumbuhan yang lebih cepat dari pada pinggulnya. Hal ini disebabkan kaki bagian depan lebih aktif bergerak pada saat pedet menyusu pada induknya. Perbedaan tuntutan fisiologis dan fungsional yang berbeda berakibat pula perbedaan urutan pertumbuhan (Sampurna et al., 2013). Hasil karakterisari tinggi pundak sapi Bali jantan pada lokasi penelitian adalah sebesar $86,92 \mathrm{~cm}$ untuk anak sapi jantan, 96,98 cm untuk pedet jantan, dan 116, $93 \mathrm{~cm}$ untuk jantan dewasa. Bila Panjang badan yang juga memiliki korelasi positif dengan tingginya bobot badan mencerminkan memudahkan dalam mencari bibit pengganti lebih awal, mengurangi biaya ternak pengganti dan kemungkinan tercapainya masa hidup yang panjang (Vergara et al., 2009). Hasil pengukuran terhadap panjang badan sapi Bali jantan pada peternakan rakyat di lokasi penelitian untuk kategori umur kurang

Ukuran tubuh yang besar juga dikaitkan dengan penggunaan jantan sebagai calon pejantan untuk mengawini betina oleh sebagian peternak sehingga kriteria yang dipilih adalah ternak yang lebih besar. Semua ukuran tubuh (lingkar dada, tinggi pundak dan panjang badan) sapi Bali jantan dengan kategori umur muda $\left(\mathrm{I}_{0}\right)$ sampai dewasa $\left(\mathrm{I}_{2}\right)$ hasil penelitian ini masih tergolong rendah dan belum memenuhi standar dari tiga kategori kualitas dibandingkan dengan standar ukuran vital bibit calon pejantan sapi Bali pada kategori umur 1,5 sampai 2 tahun untuk tinggi pundak yaitu sebesar $110 \mathrm{~cm}$, maka hasil penelitian tidak berbeda jauh walaupun masih tergolong rendah. Sapi Bali jantan pada lokasi penelitian dapat dikategorikan sebagai sapi yang kurus, karena kondisi lingkar dadanya yang kecil namun memiliki tinggi badan yang tidak telalu berbeda jauh dengan ukuran standar. Pengaruh variasi umur, dan sistem pemeliharaan dapat disinyalir sebagai faktor penyebabnya.

dari 1 tahun, 1-2 tahun dan lebih dari dua tahun diperoleh masing-masing adalah sebesar 84,07 cm, 96,61 cm, dan 112,22 cm. Hasil penelitian menunjukkan panjang badan sapi Bali jantan masih tergolong rendah bila dibandingkan dengan ukuran vital bibit calon pejantan sapi Bali pada kategori umur 1,5 sampai 2 tahun untuk panjang badan yaitu sebesar $122 \mathrm{~cm}$.

bibit yang ditetapkan Direktorat Jenderal Peternakan Departemen Pertanian (Deptan, 2006). Seleksi yang lebih terarah dan pengaturan perkawinan yang lebih terkontrol perlu dilakukan untuk meningkatkan kualitas bibit sapi Bali jantan sebagai calon pejantan yang berkualitas bagi pelestarian dan pengembangan populasi dan produktivitas sapi Bali (Hardjosubroto, 2004). 


\section{KESIMPULAN}

Berdasarkan hasil penelitian dapat disimpulkan pola warna bulu sapi Bali semuanya normal dengan proporsi merah bata mengkilap dan pudar masing-masing sebesar $64 \%$ dan $36 \%$. Lingkar dada, tinggi pundak

\section{DAFTAR PUSTAKA}

Afolayan, R.A., Deland, M.P.B., Rutley, D.L., Bottema, C.D.K., Ewers, A.L., Ponzoni, R.W., \& Pitchford, W.S. 2002. Prediction of carcass meat, fat and bone yield across diverse cattle genotype using live-animal measurements. Anim. Prod. Aust. 24:13-16.

Alamsyah, M S. 2015. Struktur Populasi Dan Persentase Warna Bulu Sapi Bali Yang Menyimpang Dari Warna Bulu Standar Bibit. [Skripsi]. Fakultas peternakan Universitas Matram, Mataram.

Baharun, A., H.L.L. Belli, dan T.M. Hine. 2017. Karakteristik Pejantan Muda Sapi Bali Pada Peternakan Rakyat Di Desa Merbaun Kabupaten Kupang. Jurnal Peternakan Nusantara. 3(1): 11 -16 .

Cam, M A., M. Olfaz, \& E. Doydan. 2010. Body measurements reflect body weights and carcass yields in Karayaka sheep. Asian Journal of Animal and Veterinary Advances. 5(2): 120-127.

Chamdi, A.N. 2005. Karakteristik Sumberdaya Genetik Ternak Sapi Bali (Bos- Bibos) dan Alternatif Pola Konservasinya. Biodiversitas. 6(1): 70-75.

Cholissodin, I., A.A Soebroto, dan N. Hidayat. 2015. Klasifikasi Citra Bibit Unggul Sapi Bali Berdasarkan Performa Warna Menggunakan Metode Fuzzy Additive Support Vector Machine (FASVM). Prosiding Konferensi Nasional Sistem Informasi (KNSI); Universitas Klabat Airmadidi, Minahasa Utara, Sulawesi Utara, 26-27 Februari 2015. hlm 163169. dan panjang badan untuk umur $<1$ tahun $\left(\mathrm{I}_{0}\right)$ adalah sebesar 108,47, 86,92, dan 84,07 cm ; untuk umur 1-2 tahun $\left(\mathrm{I}_{1}\right)$ sebesar 120,62, 96,98, dan 96,61 cm ; sedangkan untuk umur $>2$ tahun $\left(\mathrm{I}_{2}\right)$ masing-masing sebesar 144,75, 116,93 , dan $112,22 \mathrm{~cm}$.

Deptan [Departemen Pertanian]. 2006. Peraturan Menteri Pertanian Nomor 54/Permentan/OT.140/10/2006 tentang Pedoman Pembibitan Sapi Potong yang Baik (Good Breeding Practice). Jakarta: Departemen Pertanian.

Dauda, A., Anya, M.I., Ayuk, A.A., Okon, B.I., \& Eburu, P.O. 2018. Application of morphological indices and distribution of qualitative traits of cattle in Obudu grass plateau-cross river state. J Res Rep Genet. 2(3): 5-9.

Gunawan, A., dan B. W. Putera. 2016. Aplikasi Linier Ukuran Tubuh untuk Seleksi Fenotipik Bibit Induk Sapi PO di Kabupaten Bojonegoro. Jurnal Ilmu Produksi dan Teknologi Hasil Peternakan. 04(3): 375-378.

Gwaza, D.S., Yahaya, M., \& Ahemen. T. 2018. Variation and distribution of qualitative traits of the Savannah Muturu on free range in the Benue trough of Nigerian. $J$ Res Rep Genet. 2(1): 33-43.

Handiwirawan E, dan Subandriyo. 2004. Potensi dan keragaman sumber daya genetic sapi Bali. Prosiding Lokakarya Seminar Naisonal Sapi Potong; Yogyakarta, 8-9 Oktober 2004. Bogor: Pusat Penelitian dan Pengembangan Peternakan dan Loka penelitian Sapi Potong Badan Penelitian dan Pengembangan Pertanian.

Hardjosubroto, W. 2004. Alternatif kebijakan pengelolaan berkelanjutan sumberdaya genetik sapi potong lokal dalam sistem perbibitan ternak nasional. Di dalam: Strategi pengembangan sapi potong dengan pendekatan agribisnis dan berkelanjutan. Prosiding seminar nasional sapi potong; Yogyakarta, 8-9 Oktober 2004. hlm 29-30.

Hartati, Sumadi, dan T. Hartatik. 2009. Identifikasi Karakteristik Genetik Sapi Peranakan Ongole Di Peternakan 
Rakyat. Buletin Peternakan. 33(2): 6473.

Hikmawaty, A. Gunawan, R.R. Noor, \& Jakaria. 2014. Identifikasi Ukuran Tubuh Dan Bentuk Tubuh Sapi Bali Di Beberapa Pusat Pembibitan Melalui Pendekatan Analisis Komponen Utama. Jurnal Ilmu Produksi dan Teknologi Hasil Peternakan. 02(1): 231-237.

Hikmawaty, Bellavista, Mahmud, A.T.B.A., \& Salam, A. 2018. Korelasi Bobot Badan dan Variabel-Variabel Ukuran Tubuh Sebagai Dasar Seleksi Calon Induk Sapi Bali. Agrovital Jurnal Ilmu Pertanian Universitas Al Asyariah Mandar. 3(1): 11-13.

Ikhsanuddin, V. Margareta, A. Nurgiartiningsih, Kuswati, dan Zainuddin. 2018. Korelasi Ukuran Tubuh terhadap Bobot Badan Sapi Aceh Umur Sapih dan Umur Satu Tahun. Agripet. 18(2): 117-122.

Kaps, R., \& W. R. Lamberson. 2004. Biostatistics for Animal Science. CABI Publishing, London UK.

Kirkpatrick, F. D. 2015. Color Patterns In Beef Cattle. [Thesis]. Department of Agriculture and county governments cooperating, University of Tennessee Institute of Agriculture, U.S.

Kosgey, I.S., Baker, R.L., Udod, H.M.J., \& van Arendonk J.A.M. 2006. Successes and failures of small ruminant breeding programmes in the tropics: a review. $J$ Small Ruminant Research. 61:13-28.

Kusuma, S.B., Ngadiyono, N., \& Sumadi. 2018. The Correlation of Body Measurements and Weights of Ongole Crossbred (PO) Cattle in Kebumen Regency. Proceeding on the 7th International Seminar On Tropical Animal Production: Contribution of Livestock Production on Food Sovereingty In Tropical Countries. $p$. 880-884. September 12-14, Yogyakarta.

Lukuyu, N.N., Gibson, J.P., Savage, D.B., Duncan, A.J., Mujibi, F.D.N, \&
Okeyo, A.M. 2016. Use of body linear measurements to estimate liveweight of crossbred dairy cattle in smallholder farms in Kenya. SpringerPlus 5(63): 114.

Nsoso, B.S.J., A.A. Aganga, B.P. Moganetsi, \& S.O. Tschwenyane. 2003. Birth weight, body condition score and heart girth in indigenous Tswana goats during dry and wet season in southeast Bostwana. Livest. Res. for Rural Develop. 15 (4): 154-158.

Pundir, R.K., Pathak B.L., \& Ahalawat S.P.S. 2007. Characterization and evaluation of Kankrej breed of cattle in its native tract. Indian J Anim Sci. 77: 323-327.

Sampurna, I.P., I.K. Saka , I.G. Oka , \& P. Sentana. 2013. Biplot simulation of exponential function to determine body dimension's growth rate of Bali calf. Canadian Journal on Computing in Mathematics, Natural Scienses, Engineering and Medicine. 4(1) : 8792.

Sampurna, I. P. 2011. Standarisasi Sapi Bali. [Artikel]. Fakultas Peternakan Universitas Udayana, Denpasar.

Soekardono, Arman, C., \& Kasip, L.M. 2009, Identifikasi Grade Sapi Bali Betina Bibit Dan Koefisien Reproduksi Sapi Betina Di Propinsi Nusa Tenggara Barat. Buletin Peternakan. 33(2): 7480 .

Syaiful, F. L., Khasrad, dan S. Maulida. 2020. Identifikasi Ukuran Tubuh Sapi Bali dan Simbal (Simmental-Bali) di Kecamatan Luhak Nan Duo Kabupaten Pasaman Barat. Jurnal Sain Peternakan Indonesia. 15(2): 219-226.

Vergara, O.D., M.A. Elzo, M.F. Ceron-Munoz, \& E.M. Arboleda. 2009. Weaning weight and post weaning gain genetic parameters and genetic trends in Blanco Orejinegro-RomosinuanoAngus-Zebu multibreed cattle population in Columbia. Livestock Science. 124: 156-162. 
Zurahmah, N., \& E. The. 2011. Pendugaan Bobot Badan Calon Pejantan Sapi Bali Menggunakan Dimensi Ukuran Tubuh. Buletin Peternakan Vol. 35(3):160164. 